\title{
慢性副鼻腔炎患者の上顎洞内細菌叢
}

\author{
八井田昌志・内藤 雅夫・岩田 重信 \\ 西村 忠郎・中西 泰夫・岡田 貞二
}

\section{Bacterial Examination of Chronic Sinusitis}

\author{
Masashi Yaida, Masao Naitoh, Shigenobu Iwata, \\ Tadao Nishimura, Yasuo Nakanishi and Teiji Okada \\ (Fujita-Gakuen University)
}

Aerobic and anaerobic bacterial examination in chronic sinusitis was performed using the specimens from maxillary sinuses collected during operation using sterilized syringes and "Kenki-porter" (porter for culture of anaerobic bacteria), and also extracted maxillary membranes were examined pathologically. Two hundreds and twenty-one strains of bacteria were obtained.

The results were as follows:

1) The rate of incidence of bacteria from the maxillary sinuses was $73 \%$. Aerobic bacteria occupied $90 \%$ and anaerobic bacteria $10 \%$ of all the cultured bacteria.

2) The most frequently found was Staphylococcus epidermidis (19\%), followed by $\alpha$-Streptococcus (16\%), Haemophilus influenzae (13\%), and Staphylococcus aureus $(7 \%)$ in patients with chronic sinusitis.

3) Streptococcus pneumoniae in chronic cases was less frequent than those in acute cases. Indigenous bacteria was frequently found in chronic conditions were highly founded rather than in acute conditions.

4) Pathologically, bacteria was found more frequently in the infiltrated type of mucous membrane, than that in other pathological types of mucosa.

目的

近年の抗生剤の進歩及びその使用頻度の増大は顕著であり, 菌交代現象および耐生菌の出現等 は, 臨床上不可避の問題である.

我々はそれら種々の環境の変化に伴なう, 慢性副鼻腔炎の病態の変化, および洞内細菌叢の変化 に興味を持ち, 上顎洞内膿の細菌学的検討および粘膜病変の病理学的検討を行なったのでそれにつ いて言及した。

実 験 対 象

実験対象は，表 1 の如く，昭和50年 9 月か 健衛生大学耳鼻咽喉科において, 慢性副鼻腔炎 ら, 昭和 57 年 4 月の 6 年 8 ケ月間に, 名古屋保少診断され, 上顎洞篩骨洞根本手術を施行し 
表 I

\begin{tabular}{|c|c|c|c|c|c|c|c|c|}
\hline & 10 & 20 & 30 & 40 & 50 & 60 & $\begin{array}{c}70 \\
\text { 才台 }\end{array}$ & 計 \\
\hline$\hat{\delta}$ & 12 & 33 & 62 & 33 & 17 & 6 & 2 & 165 \\
\hline 우 & 7 & 23 & 5 & 6 & 12 & 1 & 3 & 57 \\
\hline 計 & 19 & 56 & 67 & 39 & 29 & 7 & 5 & 222 \\
\hline & 䜌 & 222 & & $\begin{array}{r}\text { 検 } \\
\text { 非検 }\end{array}$ & & 62洞 & & $73 \%$ \\
\hline
\end{tabular}

た. 男子165洞，女子57洞の計222洞であった。 また, 比較の為に, 鼻副鼻腔疾患を有しない

当院新患 10 名に対して鼻腔内細菌を検索した.

\section{実 験 方 法}

(1)材料採取法：上顎洞内分泌物は，上顎洞篩 骨洞根本手術施行中, 犬歯窩開放時に, 注射器 にて洞内分泌物を無菌的に吸引採取し, 直ちに 「ケンキポーター」に入れ保存した。分泌物が 非常に粘稠で吸引採取不可能な場合には，上顎 洞粘膜切開時, ガーゼを挿入し, それに附着せ る分泌物をガーゼとよむに「ケンキポーター」 に入れた。

(2)分離・培養・同定: 名古屋保健衛生大学病 院中央検查室にて施行した，Gram 染色にて鏡 検後, 好気性菌に対しては血液寒天培地, チョ コレート寒天培地, デスオキシコレート培地, あしくはD H L 寒天培地を使用し, 嫌気性菌に
対しては, GAM半流動培地にて, 増菌培養後 に, GAM寒天培地を使用した。 又, 検出菌の 㽝剤感受性は昭和ディスクの 1 濃度ディスクに より, $3+, 2+, 1+,-$, の 4 段階に判定 し, $3+, 2+$ を感受性ありとした。

(3) 上顎洞粘膜の病理学的検査 : 上顎洞粘膜 は, 手術時摘出したものを, 10\%ホルマリンに て周定後, パラフィン包埋し, 薄切後, ヘマト キシリン・エオジン染色を施行し，鏡検した。

そして Manasse の分類に従い, 浮腫型, 肉 芽型（漫㵎型），線維型，混合型の 4 型に分類 した.

\section{実 験 結 果}

上顎洞内の検出菌は, 表 2 の如く, 好気性 た。 菌においては，グラム陽性球菌で, Staphylococcus epidermidis 42 株, $x$-streptococcus 36株, Staphylococcus aureus 16株, Micrococcus 7 株, $\beta$-streptococcus 6 株, $\gamma$-streptococcus 4 株, Streptococcus pneumoniae 4 株の順に多く検出された .

グラム陽性桿菌では, Corynebacterium が 3 株検出された.

グラム陰性球菌では Neisseria 属が 8 株, Acinetobacter calcoaceticus 4 株が検出され

グラム陰性桿菌では，Haemophilus influenzae 28株, Klebsiella pneumoniae 9 株, Escherichia coli 3 株, Pseudomonas aeruginosa 3 株, Serratia 属 2 株, Enterobacter cloacae 2 株, Haemophilus parainfluenzae 2 株, Citrobacter 属 2 株の順に検出され, Haemophilus influenzae の検出率の高いのが 著明であった。

次いで嫌気性菌であるが, グラム陽性球菌で は, Peptococcus 5 株, Peptostreptococcus 
好気性菌

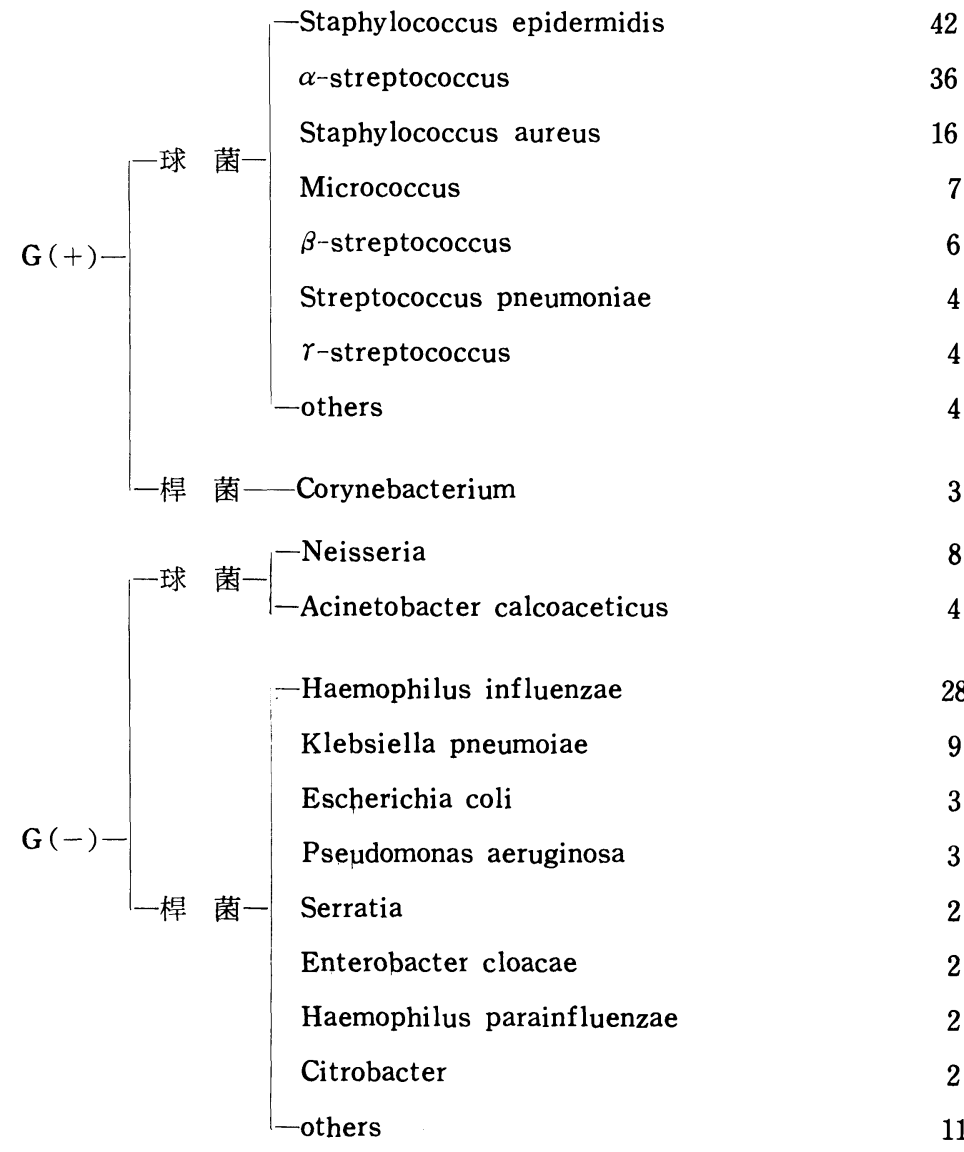

株数

42

36

16

7

6

4

4

4

3

8

4

28

9

3

3

2

2

2

2

11

嫌気性菌

$$
\begin{aligned}
& G(+)-\left.\right|_{\text {一桿 }} ^{\text {菌—- Lactobacillus }}
\end{aligned}
$$

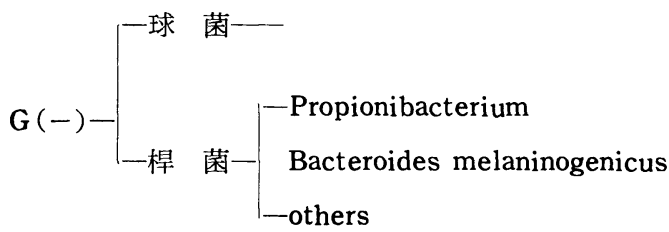

真菌

Mucor

Candida albicans 
3 株が検出された。

グラム陽性桿菌では，Lactobacillus が 3 株 検出された。

グラム陰性桿菌では, Propionibacterium 4 株, Bacteroides 3 株であった。

また，真菌では, Mucor 2 株, Candida albicans 1 株が検出された.

以上，細菌を検出したのは，222洞中，162洞 で約 $73 \%$ でった，又嫌気性菌の検出率は， 22 洞，約 $10 \%$ あったた。嫌気性菌の検出率は馬 場1) らの報告に比して低かったが，当院中央検 査室にて, 昭和 57 年 5 月より, ガスチェンバー の使用を開始しており，それ以降では検出率の 向上がややみられた。

次に，各洞において何種の菌が検出されたか について調べてみた。表 3 の如く 1 種検出洞が 12 洞， 2 種検出洞が 41 洞， 3 種検出洞が 9 洞で あり，多種検出洞の内で，好気性菌之嫌気性菌 とが同時に検出されたのは，50洞中，9洞で18 \%であった。

なお，正常人の鼻腔内検出菌は，表 4 の如く Staphylococcus epidermidis 5 株, Coryneba-

表 3

\begin{tabular}{|c|c|c|c|c|}
\hline \multirow[t]{3}{*}{1 種 } & 112洞 & \multirow{2}{*}{\multicolumn{2}{|c|}{\begin{tabular}{|} 
一好気性菌 \\
嫌気性菌
\end{tabular}}} & 97洞 \\
\hline & & & & 13 \\
\hline & & \multicolumn{2}{|l|}{ 一真 } & 2 \\
\hline \multirow[t]{2}{*}{2 種 } & \multirow[t]{2}{*}{ 41洞 } & 一好気性菌 & 2 種 & 35 \\
\hline & & $\begin{array}{l}\text { 好気性菌 } \\
\text { 嫌気性囷 }\end{array}$ & ) & 6 \\
\hline \multirow[t]{3}{*}{3 種 } & \multirow[t]{3}{*}{9 洞 } & 一好気性菌 & 3 種 & 5 \\
\hline & & $\begin{array}{l}\text { 好気性菌 } \\
\text { 嫌気性菌 }\end{array}$ & $\begin{array}{l}2 \text { 種 } \\
1 \text { 種) }\end{array}$ & 3 \\
\hline & & $\begin{array}{c}\text { 好気性菌 } \\
\text { - 真 }\end{array}$ & $\begin{array}{l}2 \text { 種 } \\
1 \text { 種) }\end{array}$ & 1 \\
\hline
\end{tabular}

非検出洞

59 洞 cterium 3 株, $\alpha$-streptococcus 2 株, Neisseria spp 2 株で，細菌検出しなかったのは， 10名中 2 名 $20 \%$ あったた。

主要検出菌の薬剤感受性は，表 5 の如くであ った. Staphylococcus epidermidis に対して, AB-PC は 18 株中 14 株 $77.8 \% ， \mathrm{CER} 17$ 株 中 17 株 $100 \%$ に対して有効であり, Staphylococcus aureus では，AB-PCは 14 株中 2 株

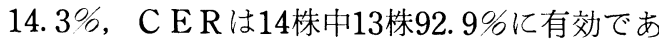
った. Haemophiuls influenzae では, AB-PC は 27 株中 21 株 $77.8 \%, \mathrm{CER} 27$ 株中 21 株 77. 8\%に対して有効であった。 又, Klebsiella pneumoniae では，CERに対して9株中 9 株 100\%に有効であった。

次いで，嫌気性菌についてみる之，Peptococcusでは AB-PCは 5 株中 4 株 $80 \%$ ，C E R む 5 株中 4 株 $80 \%$ 亿有効であり, Peptostreptococcusに対しては，AB-PC, CER ともに 3 株 中 3 株有効であった。

上顎洞粘膜の病理学的検査では， Manasse の分類による浮腫型が151洞中 68 洞 (45\%), 線 維型が37洞 $(24.5 \%)$ ，浸潤型もしくは肉芽型 が 7 洞 (4.5\%)，混合型が39洞（26\%）であっ た。备型の細菌検出率は，それぞれ $75 \% ， 78$ $\%, 88 \%, 72 \%$ て浸潤型の検出率が高いが，乙 れは例数が少ない為に明確には判断できなかっ た.

表 4 正常鼼腔よりの検出菌（10名）

\begin{tabular}{ll}
\hline \hline Staphylococcus epidermidis & 5 株 \\
Corynebacterium & 3 \\
$\alpha$-Streptococcus & 2 \\
Neisseria & 2 \\
Staphylococcus aureus & 1 \\
Haemophilus influenzae & 1 \\
非検出 & 2 名 $(20 \%)$
\end{tabular}


(1) Staphylococcus epidermidis

\begin{tabular}{l|c|cc|cc}
\hline & 株数 & $3+$ & $2+$ & + & - \\
\hline A B-P C & 18 & 13 & 1 & 4 & \\
C E R & 17 & 17 & & & \\
G M & 18 & 16 & 2 & & \\
E M & 16 & 9 & 1 & & 6 \\
L C M & 14 & 8 & & 1 & 5 \\
T C & 17 & 10 & 1 & 3 & 3 \\
C P & 18 & 14 & 3 & & 1
\end{tabular}

Staphylococcus aureus

\begin{tabular}{l|c|cc|cc}
\hline & 株数 & $3+$ & $2+$ & + & - \\
\hline A B - P C & 14 & 2 & & 6 & 6 \\
C E R & 14 & 9 & 4 & & 1 \\
G M & 14 & 14 & & & \\
E M & 13 & 1 & & & 12 \\
L C M & 11 & 2 & & & 9 \\
T C & 14 & 2 & 1 & 8 & 3 \\
C P & 14 & 7 & 2 & 5 &
\end{tabular}

Haemophilus influenzae

\begin{tabular}{l|c|cc|cc}
\hline & 株数 & $3+$ & $2+$ & + & - \\
\hline A B - P C & 27 & 20 & 1 & & 6 \\
C E R & 27 & 20 & 1 & 3 & 3 \\
G M & 27 & 25 & 1 & & 1 \\
E M & 21 & 4 & 12 & 4 & 1 \\
L C M & 9 & & 1 & 5 & 3 \\
T C & 25 & 24 & & 1 & \\
C P & 27 & 27 & & &
\end{tabular}

考

細菌感染は，慢性副鼻腔炎発症の成因及び病 像に重要な役割を演じていると考えられ，過去 にも上顎洞内細菌叢の検索は何回となく行なわ れている.そこで1970年の馬場12) の報告と比 較してみた。その結果は，表6の如くであっ た。このうちで相違点をあげていくと，まず第 1 に, 当教室では $\alpha, \beta, \gamma$, の連鎖球菌の検 出率が高いことである。馬場の報告においては $2.4 \%$ に過ぎないのに対し，20.4\%にも達して
(2) Klebsiella pneumoniae

\begin{tabular}{l|c|cc|cc}
\hline & 株数 & $3+$ & $2+$ & + & - \\
\hline A B-P C & 9 & & & 6 & 3 \\
C E R & 9 & 9 & & & \\
G M & 9 & 9 & & & \\
E M & 4 & 3 & & \\
C L D M & 4 & 4 & & \\
T C & 9 & 9 & & \\
C P & 9 & 9 & &
\end{tabular}

\section{Peptococcus}

\begin{tabular}{l|c|cc|cc}
\hline & 株数 & $3+$ & $2+$ & + & - \\
\hline A B-P C & 5 & 4 & & 1 & 1 \\
C E R & 5 & 4 & & & \\
G M & 2 & 1 & & 1 & \\
E M & 4 & 2 & & & 2 \\
L C M & 4 & 3 & & & 1 \\
T C & 5 & 3 & 1 & 1 & \\
C P & 5 & 5 & & &
\end{tabular}

Peptostreptococcus

\begin{tabular}{l|c|cc|cc}
\hline & 株数 & $3+$ & $2+$ & + & - \\
\hline A B - P C & 3 & 3 & & \\
C E R & 3 & 3 & & & \\
G M & 3 & & 1 & 1 & 1 \\
E M & 2 & 2 & & & \\
L C M & 3 & 2 & 1 & & \\
T C & 3 & 2 & 1 & \\
C P & 3 & 3 & &
\end{tabular}

按

いる. 次いで Haemophilus iufluenzae む4.6 \%に対して $12.4 \%$ と高值を示した。

一方検出率が低かったのは, Pseudomonas aeruginosa が $7.3 \%$ に対して $1.3 \%$ ，および嫌 気性グラム陽性球菌の Peptococcus と Peptostreptococcus が，具場の報告では，9.7\%， $10.9 \%$ 対して当教室ではそれぞれ $2.2 \%$ と 1.8 \%であったことである.

以上が主な相違点であるが, 馬場以前の報告 
表 6

\begin{tabular}{|c|c|c|}
\hline & 当教室 & 馬場 \\
\hline Staphylococcus epidermidis & $18.6 \%$ & $19.4 \%$ \\
\hline Staphylococcus aureus & 7.1 & 8.7 \\
\hline Streptococcus pneumoniae & 1.8 & 3.2 \\
\hline \multirow[t]{2}{*}{ Streptococcus } & $2.7)$ & 1.2 \\
\hline & $1 . 8 \longdiv { 2 0 . 4 }$ & \begin{tabular}{l|l}
1.2 & 2.4
\end{tabular} \\
\hline viridans & 15.9 & -1 \\
\hline Corynebacterium & 1.3 & - \\
\hline Neisseria & 3.5 & - \\
\hline Haemophilus influezae & 12.4 & 4.6 \\
\hline Klebsiella pneumoniae & 4.0 & 4.9 \\
\hline Pseudomonas aeruginosa & 1.3 & 7.3 \\
\hline Escherichia coli & 1.3 & 1.2 \\
\hline Citrobacter & 0.8 & - \\
\hline Proteus & - & 3.2 \\
\hline Peptococcus & 2.2 & 9.7 \\
\hline Peptostreptococcus & 1.8 & 10.9 \\
\hline Lactobacillus & 1.3 & - \\
\hline Propionibacterium & 1.8 & 0.8 \\
\hline Bacteroides & 1.3 & 2.8 \\
\hline others & $19.0 \%$ & $21.0 \%$ \\
\hline
\end{tabular}

と比較をしてみると ${ }^{6)}$, Haemophilus influenzae の検出率は, 当科の報告と同様に高率で あった。逆に Staphylococcus epidermidis の 検出率が以前より高くなってきている，同時 に Staphylococcus aureus の検出率の低下が 認められる. この様に，近年 Staphylococcus aureus が減少し, Staphylococcus epidermidis が増加してきているのは，セフェム系の抗生剤 の使用頻度が増大し，それに対し高感受性を持 $つ$ Staphylococcus aureus の検出頻度が低下 したのではないかと推測される.

次いで, 急性鼻副鼻腔炎患者よりの検出菌之 の比較であるが，出口 ${ }^{3)}$ の報告と比較すると， その差異は明瞭である。すなわち, Staphylococcus aureus $11.4 \%, \beta$-streptococcus $7.7 \%$, Streptococcus pneumoniae $45.5 \%$, Haemophilus influenzae $15.4 \%$ と, この 4 菌種で 80 \%を占めた。 それに対し当教室では 4 菌種で 24 \%, 馬場では17.7\%に過ぎなかった.とのうちで も Streptococcus pneumoniae の検出率の相
違は压倒的であった。しかし Staphylococcus aureus や Haemophius influenzae では大差 は認めなかった。とれは上気道感染症患者より の上咽頭部採取粘液の検出菌の動態之比較的類 似している4).

次に, 1 種検出洞に関してみてみると, 鼻腔 内の定着常在細菌占である, Staphylococcus epidermidis (24\%), $x$-streptococcus (13\%), Neisseria spp ( $3 \%)$ の 3 種の菌で $40 \%$ 占 めた。 それに対し病原性菌の Haemophilus influenzae (17\%), Staphylococcus aureus ( $7 \%)$, Streptococcus pneumoniae $(3 \%)$

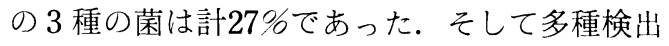
洞については, 鼻腔内常在細菌である. $x$ streptococcus, Neisseria spp. Staphylococcus epidermidis, Micrococcus spp. Corynebacterium spp.のみの組み合わせで検出されたの は, 50 洞中 13 洞 $26 \%$ で, 常在菌とその他の菌と の組み合わせで検出されたのは 20 洞 $52 \%$ あ゙あっ た. 尚, Haemophilus influenzae の単独検出 率は76\%, Staphylococcus aureus 63\%であ った.

以上まとめてみると, 常在菌のみ検出された のは，37\%と高率であったであった。このこ 之は，急性副鼻腔炎患者之慢性副鼻腔炎患者之 の細菌叢の相異となっている。すなわち(1)慢性 副鼻腔炎患者鼻腔内の定着正常常在細菌丵であ り, 病原性が弱いとされている菌が多数検出さ れており, 更にその単独検出率も高い. (2)他菌 種との混在例が多いといわれる Haemophilus influenzae よりも, Staphylococcus aureus の方が混在例がやや多かった。 (3)鼻腔内での 定着性が薄く，「起炎菌」としての価值が高い

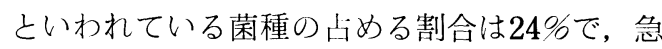
性副鼻腔炎患者の $80 \%$ に対して低く,やはり急 性期之慢性期とでは検出菌に大きな差異が認め られた。

次に検出菌の薬剤感受性についてであるが, 特記すべきは，Staphylococcus aureus に対 する $\mathrm{AB}-\mathrm{PC}$ の感受性の低さで，有効率はわ 
ずか $14.3 \%$ あったが，諸家の報告と比較して あこの值はかなり低值であった。

表 7 は, 上顎洞粘膜の病理学的分類々検出菌 との関係をみたものであるが，浸潤型の例数が
少なく明確な判断はできないが，炎症細胞が著 明な浸潤型に細菌検出率が高かった。又，浸潤 型には，グラム陰性桿菌の検出頻度が高かっ た。

表 7

\begin{tabular}{|c|c|c|c|c|c|}
\hline & & 浮 腫 型 & 線 維 型 & 浸 潤 型 & 混合型 \\
\hline \multirow{7}{*}{ 好 } & $\mathrm{G}(+)$ 球菌 & 37 & 17 & 5 & 15 株 \\
\hline & Staphylococcus epidermidis & 13 & 6 & 3 & 7 \\
\hline & $\alpha$-streptococcus & 15 & 7 & 1 & 2 \\
\hline & Staphylococcus aureus & 3 & 0 & 1 & 1 \\
\hline & $\gamma$-streptococcus & 2 & 2 & 0 & 2 \\
\hline & Streptococcus pneumoniae & 1 & 2 & 0 & 1 \\
\hline & others & 3 & 0 & 0 & 2 \\
\hline 気 & $\begin{array}{l}\mathrm{G}(+) \text { 桿菌 } \\
\text { Corynebacterium }\end{array}$ & 0 & 0 & 1 & 1 \\
\hline \multirow[t]{2}{*}{ 性 } & $\mathrm{G}(-)$ 球菌 & 6 & 2 & 0 & 0 \\
\hline & Neisseria & 3 & 2 & 0 & 0 \\
\hline \multirow{7}{*}{ 菌 } & Acinetobacter & 3 & 0 & 0 & 0 \\
\hline & $\mathrm{G}(-)$ 桿菌 & 31 & 8 & 5 & 6 \\
\hline & Haemophilus influenzae & 6 & 2 & 3 & 3 \\
\hline & Escherichia coli & 1 & 2 & 0 & 2 \\
\hline & Klebsiella pneumoniae & 0 & 2 & 1 & 0 \\
\hline & Pseudomonas aeruginosa & 2 & 1 & 0 & 0 \\
\hline & others & 4 & 1 & 1 & 1 \\
\hline \multirow{4}{*}{ 㨀 } & $G(+)$ 球菌 & 0 & 3 & 3 & 2 \\
\hline & Peptococcus & 0 & 2 & 0 & 1 \\
\hline & others & 0 & 1 & 3 & 1 \\
\hline & $\mathbf{G}(+)$ 桿菌 & 5 & 1 & 0 & 2 \\
\hline 気 & Lactobacillus & 4 & 0 & 0 & 0 \\
\hline \multirow[t]{2}{*}{ 性 } & others & 1 & 1 & 0 & 2 \\
\hline & G ( - ) 球菌 & & & & \\
\hline \multirow{3}{*}{ 菌 } & G ( - ) 桿菌 & 3 & 1 & 1 & 1 \\
\hline & Propionibacterium & 1 & 1 & 0 & 0 \\
\hline & others & 2 & 0 & 1 & 1 \\
\hline & Incidence of Bacteria & $75 \%$ & $78 \%$ & $88 \%$ & $72 \%$ \\
\hline
\end{tabular}




\section{ま と め}

昭和 50 年 9 月より昭和 57 年 4 月の間に, 上頢洞節骨洞根本手術を施行した 222 洞を対象に細菌学 的検查及び病理学的検査を施行し，その成績につき検討した。

1 ） 222洞より，221株の菌を分離・同定した。 その内訳は，Staphylococcus epidermidis $19 \%$, $\alpha$-streptococcus 16\%, Haemophilus influenzae 13\%, Staphylococcus aureus $7 \%$ 等であった.

2 ) Staphylococcus aureus の検出率は低く, Staphylococcus epidermidis の検出率が増加し つつあった。

3 ) 急性副鼻腔炎と比較して, Streptococcus pneumoniae の検出率が低く, 鼻腔内常在細菌叢 の検出率が高かった.

4 ) 洞粘膜の病理組織学的所見から細胞浸潤の強いものに, 細菌検出率が高かった.

本論文の要旨は第20回日本鼻副鼻腔学会総会において口演した .

\section{参考文献}

1）馬場駿吉：慢性副鼻腔炎における嫌気性菌に関す る臨床的ならびに実験的研究. 名市大医誌 20 巻, 4 号 : 800 852, 1970.

2 ）高須昭男, 馬場駿吉 : 耳鼻咽喉科感染症, 鼻・副 鼻腔の感染症. 而性と化学療法, 353, 医学書院.

3 ）出口浩一：Primary infection を主とした患者か ら検出された細菌の様相一検出される菌種の特徵 についてーその 3.メディア・サークル 26(5) :235〜240, 1981 .

4) 出口浩一：Primary infection を主とした患者か ら検出される細菌の様相一検出される菌種の特徵

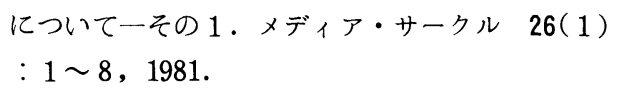

5 ) 原耕平：鼻腔における常在菌叢. 臨床細菌学, 講 義編, 37, 講談社, 1977.

6 ）志賀健治：慢性副鼻腔炎における上顎洞内細菌の 変動について日医大誌第 35 巻第 2 号 : 88〜 104, 1968.
別刷請求先：八井田昌志
干470-11 豊明市沓掛町田楽ヶ䆶 1-98
名古屋保健衛生大学医学部耳鼻咽喉科学 